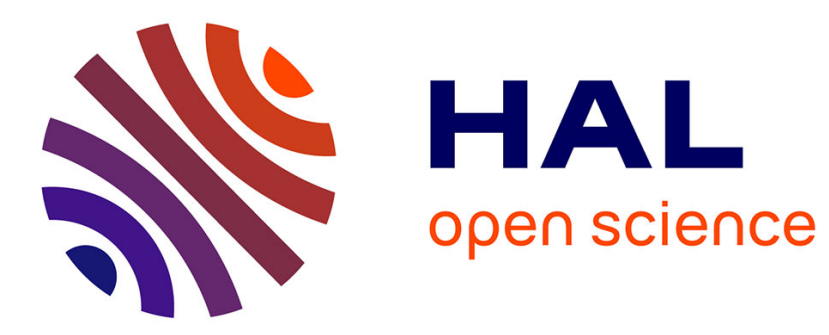

\title{
This is not a Festival. Transhumance-Based Economies on Turkey's Upland Pastures
}

\author{
Nicolas Elias
}

\section{To cite this version:}

Nicolas Elias. This is not a Festival. Transhumance-Based Economies on Turkey's Upland Pastures. Nomadic Peoples, 2016, 20 (2), pp.265-286. 10.3197/np.2016.200206 . hal-03177162

\section{HAL Id: hal-03177162 \\ https://hal.science/hal-03177162}

Submitted on 14 Jun 2021

HAL is a multi-disciplinary open access archive for the deposit and dissemination of scientific research documents, whether they are published or not. The documents may come from teaching and research institutions in France or abroad, or from public or private research centers.
L'archive ouverte pluridisciplinaire HAL, est destinée au dépôt et à la diffusion de documents scientifiques de niveau recherche, publiés ou non, émanant des établissements d'enseignement et de recherche français ou étrangers, des laboratoires publics ou privés. 


\title{
THIS IS NOT A FESTIVAL. TRANSHUMANCE-BASED ECONOMIES ON TURKEY'S UPLAND PASTURES
}

\author{
Nicolas Elias
}

(Translated by Saskia Brown)

\begin{abstract}
This article sets out to study how an instituted practice of pastoral societies has evolved under the industrialised, capitalist Turkey of the last decade. In the Pontic Mountains, in north-eastern Turkey, the celebrations that take place every summer on the upland pastures are some of the most eagerly-awaited events. Until recently they were related to pastoralism and transhumance. But, although pastoralism has collapsed, the number and popularity of these events is growing yearly. When the ethnographic study of the most famous of them (Kadirga) is related to recent social transformations in Turkey (migration, development of the culture industry, urbanisation, etc.), it becomes clear how such celebrations are instrumentalised by the new political economy. This leads us to re-examine the question of the culture industry (Adorno 1964).
\end{abstract}

\section{KEYWORDS}

Transhumance, pastoral economy, culture industry, festival, Trabzon, Turkey.

\section{INTRODUCTION}

What becomes of a world when its system of production collapses? Can studying its celebrations provide an answer? In this article I shall explore how a particular instituted practice of pastoral societies has been reinvested and recast: a series of celebrations taking place on the upland pastures of the Pontic Mountains in the province of Trabzon in northeastern Turkey. Using these festivities as a way of situating the place of transhumance in the district, I shall suggest that transhumance today is no longer conceived as a sustainable economic activity, but as part of the culture industry, ${ }^{1}$ and as an ideological investment.

\footnotetext{
${ }^{1}$ Theodor Adorno quite rightly adds that in the expression "culture industry," "one should not take the term industry literally. It relates to the standardisation of the thing itself - for example, the
} 


\section{I - THE CALENDAR OF TRANSHUMANCE}

"There is nothing more banal than the calendar. The Republican calendar with its civic festivals, its public holidays, is something utterly unremarkable which we hardly notice. It seems to go without saying. (...) But it is a good example of how the public sphere comes into the very heart of the private sphere: at the very heart of our memory we find the State, civic, civil or religious festivals, and we find the calendars specific to different categories, such as the school calendar or the religious calendar. Thus we find a whole set of structures of temporality marked by social rhythms and collective activities".

(Bourdieu 2012)

We could add to Pierre Bourdieu's reflections here that there is also an economic calendar, and it structures the social realm no less powerfully. For example, in the Pontic Mountains running parallel to the Black Sea to the west of the Caucasus, transhumance creates its own calendar, with the alternation of wintering in the valleys and summer quarters on the upland pastures (yayla). As soon as the snows thaw, all cattle-owning families in the area leave with much pomp and ceremony for the summer pastures, often during May. The fact that everyone leaves together is less to do with the celebration of local community than with the management of resources: it ensures that no one benefits from the grazing land before the others (Zaman 2001). By contrast, the return journey takes place family by family, during the month of September.

But the main way in which the temporality of transhumance is invested by the community (a community in the process of redefinition) is by a series of celebrations, called şenlik, which take place throughout the summer months along the mountain summits. The most important of these take place on the marketplaces, which are "neutral" territories where summer grazing communities $(o b a)^{2}$ from different valleys gather. These are spaces where people meet and trade, at 2,000 m, providing a snapshot of the world of transhumance. The şenlik is above all a

standardisation of the Western, as every cinema-goer knows - and the rationalisation of distribution techniques, but it does not refer strictly to the production process". Ibid.

${ }^{2}$ Although today the Turkish word is used at times to mean "summer quarters", more generally (and historically) it means a nomadic encampment and its related community. 
long-awaited time to perform the circle dance called horon, ${ }^{3}$ which is the celebration's main activity. The period of festivities reaches its peak between mid-July and mid-August, which is when agricultural work stops briefly. This break, which straddles two months, is called "the rotten month" (çürük ayl) - the schedule of transhumance in part still uses slightly archaic language. Each month is given a specific name linked to seasonal agro-pastoral work (for example, the preceding month is called "the month of the sickle"), and the calendar referred to is the Julian Calendar (about 13 days' difference from the Georgian Calendar), which has not been officially in use since the beginning of the 20th century (Deny 1921).

In Trabzon, as in most of Turkey, pastoralism is no longer viable, and has utterly imploded, a fact which everyone now accepts. ${ }^{4}$ Some figures suffice to suggest how seriously it has collapsed:

1) The number of heads of cattle, which remained relatively stable until 1980, halved between 1980 and 2005 in the province (Bakırezer 2009 : 59);

2) The rural population of the province, as a percentage of its population as a whole, shrunk from $82 \%$ in $1965^{5}$ to $44 \%$ in $2012^{6}$.

Urbanisation and substantial economic migration to Istanbul and Europe have utterly transformed the terms of the material and symbolic economy. Although transhumance is still practised in the valleys, it can no longer play a determinant role as an economic system.

Yet not only do the old pastoral festivities live on, but they have become one of the most valued collective activities, generating the largest gatherings to be seen in the region. This is all the more surprising because they are entirely dependent on the economic regime of transhumance, and are tributary to the social world of the upland summer settlements which, although not entirely abandoned, are certainly not in their prime. Nonetheless, these festivities and their timetable occupy a prime position even in the provincial government's discourse. On

\footnotetext{
${ }^{3}$ Literally, the term means "dance", in the local Greek dialect (called Pontic Greek). This reminds us that significant numbers of Greek-speaking Christians lived in these mountains before the exchange of populations between Greece and Turkey in 1923. Some (muslim) villages still use this Greek dialect today. (Andrews and Benninghaus $1989: 145$ ).

${ }^{4}$ In Anatolia, the central authorities have continuously sought to settle the transhumant communities considered to be factors of instability - ever since the Ottoman Empire (Dumont 1975). I am unaware of any equivalent attempts for the Pontic Mountains.

5 Türkiye İstatistik Kurumu, 1965 Genel Nüfüs Sayımı Veri Tabanı.

${ }^{6}$ Türkiye İstatistik Kurumu, 2012 Genel Nüfüs Sayımı Veri Tabanı.
} 
the website of the Provincial Division for Culture and Tourism, ${ }^{7}$ and also on the tourist brochure one is given at the Trabzon tourist office, one can find the "calendar of celebrations of Trabzon's upland pastures") (Trabzon yayla şenlikleri takvimi), which lists no less than 43 events, from the first Sunday of May to 4 September.

Before taking a closer look at this calendar and the celebrations, two remarks are in order. The first relates to the word "tourism" (turizm). Leading figures in mountain communities talk a lot about it, and sing the praises of these forests which Istanbulites might want to visit - but little is actually done, and nobody comes. ${ }^{8}$ Turkish academics discuss the potential of the region for tourism (Zaman 2010 ; Çavuş et Altaş 2010), but their repeated exhortations only highlight the relative failure in practice. The only two places in the province which really draw tourists - the Sumela Monastery and the Long Lake (Uzungöl) - can be seen as day trips from Trabzon, and can in no way provide a viable source of income for the hinterland. Although - as De Planhol (1963) remarked some 50 years ago - there is a sort of "climatic tourism" in these mountains, it is principally internal, reflecting how the province's inhabitants live their new relation to the upland pastures now that transhumance has been abandoned. ${ }^{9}$

Figure 1 Map of Trabzon Province (Provincial Division for Culture and Tourism). Its southern border roughly follows the ridge of the Pontic Mountains range

My second preliminary remark is that in Turkey each administrative division is named after its administrative capital. Thus Trabzon is both the name of the town and port, the former Trebizond, and of the mountain hinterland. An identical name hides what is a real discrepancy between the industrial port, which lives through its national and international trade, with no connection whatsoever to transhumance, and the hinterland which until recently had an agro-pastoralist economy. Although this disjunction is often denied, it is an unmistakable reality.

\footnotetext{
${ }^{7}$ T.C. Kültür ve Turzim Bakanlığı, Trabzon İl Kültür ve Turizm Müdürlüğü, Trabzon yayla şenlikleri takvimi, [online], URL : http://www.trabzonkulturturizm.gov.tr/TR,57700/yayla-senlikleri.html

${ }^{8}$ However, in 1990-1991, there were some political efforts to develop tourism on certain high pastures (Zaman 2001).

${ }^{9}$ Only the high pastures of Ayder, in the neighbouring province of Rize, have become an important tourist attraction.
} 
And it is not without significance. Despite the calendar's title, the 43 "celebrations of Trabzon's upland pastures" are not all linked to transhumance and they do not all take place on the mountain tops (one of them even takes place in the town of Trabzon itself). Additionally, two terms recur in designating these festivities: ${ }^{10}$ şenlik (30 occurrences), but also festival (10 occurrences). This Latin word was imported into Turkish quite recently. Its first written occurrence, according to the linguist Sevan Nişanyan, was in $1934 .{ }^{11} \mathrm{We}$ are not concerned with this lexical shift in itself - and the transhumance celebrations can equally be referred to by dernek or panayı (both of which convey the idea of a gathering) - but rather with what the appearance of this new term signifies. In Turkey the word festival refers mostly to urban celebrations, in link with the culture industry. A further, double, differentiation is immediately noticeable on the calendar of the Provincial Division for Culture and Tourism: 1) festivals generally take place on fixed dates (4, 5 and 6 August for the Vakfikebir festival), whereas şenlik generally refer to a weekday, as in "the third Friday in July"; 2) festivals take place in towns, and even coastal towns (which have nothing to do with transhumance), whereas şenlik are on the upland pastures (with rare exceptions). Above all, even a cursory examination shows that festivals are recent institutions: 2000 for Tonya, 2003 for Vakfikebir whereas the organisers of the Sisdağı ("The misty mount") şenlik mentioned that it was at its $195^{\text {th }}$ edition in 2014 (to take a completely random example). One might assume, then, that these new celebrations are marginal additions to the pastoral celebrations which constitute the core of the calendar, especially as the locality organising a festival mostly uses it to promote one of its economic activities, for example, the festival of peaches, rice pudding, bread, butter, hazlenuts, and so forth. ${ }^{12}$ Today, however, if one attends both events, it seems that as the proportion of transhumant communities in the şenlik shrinks, so the difference between şenlik and festival lessens. A dancer summarised the feeling of a large number of local men when he said, furiously, that the Kadirga şenlik "has become like a festival now" (artık festival gibi oldu). The word festival is thus a sign of a more general renewal of interest in the whole of the

\footnotetext{
${ }^{10}$ There is one instance of şenlik being associated with festival. I shall not take into account the references to bayram (civil or religious festival) and eğlence ("entertainment" ) (one occurrence each), nor the two occurrences of anma (« commemoration»), because I did not attend these events.

11 Sevan Nişanyan, Nişanyan Sözlük. Çağdaş Türkçenin Sözlüğü, [online] URL : http://www.nisanyansozluk.com/

12 This list incidentally gives a good idea of the local products (peaches, hazelnuts and bread in the coastal towns, milk products such as rice pudding and butter in the mountain villages).
} 
calendar, disconnected from the economy of transhumance. One could suggest that this "becoming-festival" tells us something about the place of transhumance in the province today.

\section{CONFLICTING APPROPRIATIONS OF THE KADIRGA SENLIK}

What makes the dancer's declaration so surprising is that it refers to the biggest and bestknown şenlik. At 2,300 m, Kadırga is one of the highest pastures. The weekly market there draws the summer populations of at least ten surrounding districts and three different provinces. ${ }^{13}$ It is thus the nerve centre of a whole economic system. It is also one of the most "built-up" terrains, despite having no permanent inhabitants: in 1997, Mehmet Zaman counted no less than 96 activities, from the butcher to the hotel, and the chemist's to the barber's (Zaman 2000 : 289). Kadirga holds its celebrations yearly on the third Friday of July (market day and day of prayer). These are known as "the reapers' festivities" (otçular şenliği), because the date corresponds, in the transhumance calendar, to the arrival on the uplands of villagers who until then had remained down below to bring in the harvests (principally maize). The event also boasts an impressive age. ${ }^{14}$ The districts involved are mainly those whose summer quarters border on the Kadırga pastures: Tonya, Şalapazarı, Eynesil (Giresun Province) and Torul (Gümüşhane Province) ${ }^{15}$. Mehmet Zaman (Zaman 2000) reconstructs the sequence of these celebrations on the basis of accounts by the oldest participants and the practices of some of the herders from these districts: on the Thursday the groups who had remained below in the village leave for their respective summer quarters and spend the night in meetings. Then everyone gathers on the Friday on the high pastures-marketplace of Kadırga, from which they return to their quarters to end the evening. Of course today people flock to the place from the whole province, and even from further afield, since many emigrants come back specially for the festival, but just for the day. The summer transhumants are hard put to assert their old social practices alongside the mass of casual visitors.

\footnotetext{
${ }^{13}$ Turkey is divided into 81 provincial authorities (il), themselves subdivided into district authorities (ilçe).

${ }^{14}$ They were mentioned as early as 1915 by the folklorist Alparslan (Zama 2000: 284).

${ }^{15}$ Today this upland pasture is officially situated in the neighbouring province of Gümüşhane, but it is mainly used by the transhumant communities from the Trabzon valleys.
} 
In 2010 I accompanied the delegation of men from the town of Tonya, the capital of the district of the same name, which is one of the two most involved in the Kadırga şenlik. The town itself has long lived from transhumance, and its only economic activity is a dairy cooperative formed by 5 of the town's quarters and 17 surrounding villages. The Mayor's Office took charge of this collective event, and used banners and loudspeakers to remind everyone about it. The participants left on the Friday morning and not on the preceding evening, as was the custom and as their neighbours from Şalpazarı still do. One of the council employees explained to me that since some of the families had abandoned their summer quarters, it was difficult for everyone to spend the night there all together. Once they had reached the high pastures area they took care not to mix with the crowd partying in front of the central stage. They remained on the edge, by a tent which had been erected for the occasion, and around which the inhabitants of the Tonya district congregated. They danced there for a long time, accompanied or surrounded by people from the district who had come to join them. It was already mid-afternoon by the time they left their marginal position and came to the space in front of the stage for the long-awaited display. This was an event in the strong sense, during which they came forward in single file, dancing, with their own musicians, horses and a broad banner spelling "Tonya" in capital letters. They thus obliged the public in front of the stage to clear a large space for them, and they turned off the sound system. For a brief quarter of an hour they "built" (kurmak) ${ }^{16}$ a wide horon, while everyone watched attentively, after which they left for the outskirts of the celebrations again. Shortly afterwards, they left the area altogether, although the festivities were continuing on stage. It was a frustrating experience for me, who was accompanying them. We had remained at a distance from the official centre of the celebrations (the complex around the stage) for most of the time. But it was clear that the dancers from other districts whose summer quarters were linked to the Kadirga market did just the same.

In the central area, the festivities began after the call to midday prayer ( $\ddot{o g} \breve{l} l$ ) and lasted until the end of the afternoon. The focus of attention was of course the stage, which saw a stream of national politicians and regional artists. Alongside it on the left was a grandstand for local dignitaries, and on the area in front of it a vast horon formed. Participating in this collective dance was in fact the festival's main activity for those with no links to Kadirga

\footnotetext{
${ }^{16}$ The act of dancing is expressed by the verb oynamak (which also means "to play"), but the verb kurmak ("to construct", "to build") is used to refer to the performance of the horon.
} 
through transhumance. It was a mixed horon, with a majority of women, and was less technical than the male groups who had come to demonstrate their local area's dance. The crowd thronging in front of the stage or joining the horon not only belonged to no district in particular, but people even came from the town of Trabzon, or were emigrants from abroad wishing to experience this communion of shared identity.

\section{Figure 2 The Tonya men's horon at Kadırga, photographed from the stage (Elias)}

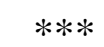

As such, the celebrations had a dual structure: far removed from the centre which monopolised the attention of an undifferentiated crowd, male groups sought to demonstrate the specificity of their local area. Thus two regimes of display and two ways of building a community cohabited through the horon, but in a dialectical rather than a simply oppositional relationship. The presence of the male dance groups provided a show for the public, while the stage-grandstand-arena complex was the real centre of attention, the focus of the local TV cameras, and a kind of "public forum". It represented for the male groups both a place for display, where they could show off their talents as dancers, and a place in which they should not mix. What these male groups really seek, through the horon dance, is distinction. The distinctiveness of the dance has two dimensions: 1) its masculinity. The type of horon danced by the male groups is called "upright" ( $d i k)$, it is virile and demonstrative, punctuated by shouts and using exaggerated movements. 2) its geographical roots. Each local area has imprinted its own particular aesthetic on the horon, its signature, and the issue of the "true" horon - or its most accomplished form - can generate unending debate among the men of these mountains.

Although these two groupings obviously come into contact at the centre of the celebrations (the arrival of the men from Tonya is an event for the audience standing in front of the stage, and it is a moment these dancers have themselves been preparing for) one can hardly ignore the resentment towards the central space felt by these men from the economically disadvantaged surrounding districts, who until recently lived from transhumance and whose presence at Kadırga represented, historically, much more than an entertainment (one among others), and a symbol of regional identity. Although this tension is often latent, it is sometimes expressed openly, but in terms which the social scientist will not 
want to hear: the traditional and "authentic" (otantik) versus the "degenerate" (yozlaşmış). Yet this discourse should not be disqualified, nor should it be taken literally. Rather, it should be considered to be the expression, by those who used to form the backbone of the old world of transhumance (the men), of the violence of their relegation. Their dispossession is expressed in the terms of the dialectic imposed upon them - that of the modern versus the traditional. ${ }^{17}$ Michael Herzfeld, in his analysis of this recourse to tradition in processes of destitution, formulates a principle which has proved its aptness time and again: "It seems clear that the specificity of the "tradition" increases with the alienation of the local protagonist" (Herzfeld 1992 : 70). One could add that people's insistence on tradition gives them access to an area of specificity, but it inevitably also generates their further alienation.

The critique of the "centre", which has "become like a festival", has two interrelated dimensions, both of which seem very far from any concerns about the economics of transhumance.

1) The first criticism concerns the horon dance. Today, simplifying somewhat, this impressive dance - and local passion - is divided into the "upright" horon (dik) - a masculine horon, the object of local pride - and a "smooth" horon (düz). The former is a long constructed sequence with local variations, which require intense interaction between the dancers and the musician, while the latter is a series of ten steps repeated over and over again. This second form is the one which has been taken up by the culture industry, since absolutely anyone can join in the dance, which thus provides the widest possible audience for the performing artists. The generalisation of the "smooth" horon, the dance of "those who do not know", has been violently criticised for the sexually and territorially undifferentiated group dance it generates. Here, knowing is knowing how to differentiate. This discourse is clearly patriarchal and conservative, characterising these geographically rooted all-male groups which remain inward-turned. By contrast, men and women of all ages and from all areas join together in the "smooth" horon performed in front of the stage. A harmonious whole, one might think, fortunately freed from the rigid constraints of the male groups. Except that this appearance of "togetherness" actually masks a disjunction at another level, that between the personalities on stage and the undifferentiated crowd. Moreover, the "upright" dance of the

\footnotetext{
17 "The modern" is often aligned in Turkey with a justification of the existing power structures.
} 
male groups is in opposition not only to its "smooth" and indistinct counterpart, but also to the stage - the dancers insist on having its sound system turned off before they agree to appear in the centre.

2) The second criticism is less explicit, and targets the stage. The stage and the grandstand are relatively recent phenomena in these celebrations in the mountains. However, their effects should not be underestimated, as Bernard Lortat-Jacob (1994: 65-66) has shown in a subtle analysis of how the addition of a stage reorganises the different groupings through the way it objectifies the distinction between actor and spectator by controlling access to visibility and to authorised speech. One of the immediate consequences of this change is that once the musician is up on stage, he takes on the aura of an $\operatorname{Artist}^{18}$ who has sole control over the music's tempo, and the dancers can thus no longer direct him. In the "upright" dance, the men put their musicians under great pressure, "building" the dance in a very strong rapport between musician and dance leader. What these men find unacceptable is to see the instrumentalists take sole control of the music, and moreover be promoted to the socially enviable status of "artists". More generally, the stage is made into the only meaningful space of public expression, the only legitimate space of political representation. This becomes clear on reading the accounts of şenlik in the local papers: they are often little more than a list of the politicians and artists who were present on stage or in the grandstand. Moreover, most of the artists and politicians ${ }^{19}$ are not even local - and even if the artists are from the region, they often live in Istanbul. The stage and the grandstand thus introduce a dialectic between the individualised "personalities" present - who do not dance - and the undifferentiated crowd which dances. In a sense, the gathering of dignitaries ends up replacing the gathering of dancers. It should be added that these two gatherings are composed exclusively of men; the mixed "smooth" horon in the centre masks what is simply a shift in the location of male domination. This shift of power toward the stage explains the ambiguous relationship of the male factions with the central space, which is for them both a space of greater visibility and a space under the domination of that stage.

\footnotetext{
${ }^{18}$ Stage performances and the music and record industry thus enable singers to go professional. Only instrumentalists can earn something from their music without this (Elias 2014) .

${ }^{19}$ Among the national politicians who were not from the region and not seeking local election were Mustafa Kara, at the Kadırga upland pastures celebrations in 2011, and Mustafa Sarıül at its counterpart at Sisdağ 1 in 2013. At the time, both were mayors of important districts of Istanbul (respectively Üskudar and Şişli). Since many emigrants from Trabzon live in Istanbul, the politicians' presence at these distant events was not electorally disinterested.
} 
I stress the issue of replacement and relegation because it embodies how these local men who take part in the celebrations have been stripped of their function of political representation. If one asks these groups why they attend nonetheless, they all give much the same reply: in order to "express" (ifade etmek) their local area, whose "representatives" (temsilci) they are. This sense of dispossession is the primary reason for their criticism of what the celebrations have become. As one of them said, "It has become 'Hello, thank you for coming, goodbye'" (güle güle gel güle güle git gibi olmuş).

What generates the most criticism from these men and appears as symptomatic of their political destitution - namely the stage and this "smooth" undifferentiated and "apolitical" way of dancing - is precisely what today appears to be indispensable in the summer events calendar in its new guise. Exaggerating a little, one could say that today the event is the stage. This might appear highly reductive, but it bears closer scrutiny. Although the stage is an increasingly costly investment, and the artists come from further and further afield, these costs precisely justify not investing in the local area, in the social practices of the summer transhumants and in the presence of many local participants - or rather, it justifies transforming these into an indistinct mass. The exclusive focus on the stage explains why the Kadirga şenlik has become "like a festival", and shows clearly how the distinctions between the two have been eroded. At the Sultan Murat şenlik, by no means a little-known celebration, the stage performance is the only event of the day. The same is true in most other places too. The "upright" dance is not excluded, on the contrary, these male dances are all the rage, and every festival feels obliged to have one. But they are performed on stage, as a show, and by semi-professional dancers. In the district of Akçaabat, an "international" folk dance festival is held on the coast, in the district's capital, in association with the Hidirnebi şenlik on the high pastures - also one of the most important in the province. The latter is blatantly made to serve the interests of the former (which celebrated its 24th year in 2014), including contributing the added value of the historical name of şenlik. The men from the handful of villages higher up the valley who continue to attend the şenlik do not attend the festival. The male horon is nevertheless performed at the festival, but by "folk" groups (ekip) of young men trained at Akçaabat's Conservatoire or its Horon, Youth and Sports Club (and the certificates delivered by such urban institutions represent another way in which the men from rural areas are stripped of power). The horon figures on the Town Hall's emblem, and a well-known 
restaurant organises demonstrations of this dance for diners. Another study by Michael Herzfeld, concerning Sean Damer's work on Crete, applies to our findings here: "this affective masculinity, which characterises the men of Crete's mountainous regions, has become a commodity which is perhaps useful to Greek nationalists and the tourist industry in Crete, but it certainly expresses a situation in which people do not control their economic future and are themselves transformed into commodities" (Herzfeld 1992: 70). It is quite right to point out that tranhumance and transhumant populations are transformed into commodities through their show value. More precisely, into "traditional" commodities, that is, into cultural products. By teasing out the logical link between economic bankruptcy and this commodification we can conceptualise the relation between the end of transhumance as a viable economic system and the appearance of the festival as the spectacle of transhumance.

\section{THE FESTIVAL AS A PRODUCTIVE MISUNDERSTANDING}

Let us leave behind our Pontic Mountains for a moment. Since the time when, according to Sevan Nişanyan, the word festival entered the Turkish language (1934), it has been fleshed out as a concept, and has become integral to the country's public sphere (Yardımc1 2014). Today it is a political method for managing militant alterity, whether "ethnic" or religious. Since festivals bring together a discourse, a practice (mainly music and dance), a public and the authorities - those entitled to speak not only to this public but in its name - they constitute a not insignificant, even if secondary, vehicle for the development and dissemination of the identity-based politics which occupies the public terrain in Turkey today.

Elise Massicard has examined one of the most important discourses of this type to have emerged in recent decades, namely Alevism, which lays claim to a separate status within mainstream Islam. Significantly, it emerged at the same time as did migration to urban centres by populations which until then had been almost exclusively rural, and riven by irreconcilable particularist currents. She formulated two extremely useful ideas in this research (2005), especially from her analysis of the Hacı Bektaş festival: 
1) the notion of neutralisation through presentation as a spectacle. In the case of the Hacıbektaş festival, what was neutralised was the event's religious charge, when the ceremony became a show. More generally it is the heterogeneity of the participants which is effaced in the unified spectacle of the culture displayed on stage. This is why one can say that the festival seeks to manage, rather than "express", alterity.

2) the notion that neutralisation can help establish a productive misunderstanding. Elise Massicard notes that "cultural markers enable anyone to be part of a transmission of a heritage without having to reflect on Alevism" (Massicard 2005 : 203). Further on, "No ideological struggle seems to mark this staging of Alevite culture, such that there is an appearance of unity and harmony both within the group and outside it" (Massicard 2005 : 203-204). One could usefully put it the other way round: the misunderstanding is productive. Bourdieu says just this when he notes that "vagueness has a social function (...), the most unassailable criteria are the least easily defined" (Bourdieu 1992: 198). Vagueness has a social function, and misunderstanding is socially productive: the spectacle of a culture can generate a vague social category which can nevertheless enjoy a broad consensus.

How are these remarks relevant to the Trabzon celebrations and the future of transhumance? Especially since in this case the particularist discourse is perfectly consistent with the national narrative, even if it cannot be reduced to it. Let us suggest provisionally that the festival "neutralises" because the stage is the only place for speech and authorised action, and as such is closely monitored. Access to the stage is restricted, and only those accredited by the institutions financing the event are entitled to have their show "produced".

The stage also generates semantic reworkings. As described above, within the şenlik as a space where transhumant groups from different valleys meet up, the male "upright" dance is a system for differentiating strong territorial attachments. Likewise for the women's traditional costumes, which are broadly similar, but display a whole spectrum of colours and motifs characteristic of a particular locality. The actions of the men and the clothes of the women thus function as elements of territorial differentiation. However, although both are amply displayed on stage during festivals, they take on a different meaning, or rather they are emptied of some of their differential meaning and end up representing an undifferentiated 
regional culture. They are no longer a language negotiating singularities, but the image of a common culture. No longer in relation to each other, but all dialectically opposed to "the modern". To cite Christian Bromberger, they no longer function as techniques ${ }^{20}$ or as signs, "the systematic markings of a statutory identification", but solely as symbols, "the translation of underlying mental schemas or ideological themes" (Bromberger 1979 : 139).

\section{Figure 3 Traditional women's costumes, generally worn by children today (Elias)}

These festivals are saturated with references to the world of transhumance: costumes, dances, songs, images of lush green valleys, names of high pastures, etc., but these function as the cultural construction of a "region" - the Pontic Mountains - and a "culture of transhumance" which could be anywhere. The spectacle of transhumance thus partially undermines the claims made by the male groups and blurs the territorial differentiations. What is neutralised is the play of distinctions and oppositions structuring these rural valleys, the system of structural differences which made of Trabzon province a collection of fiercely defended singularites. This neutralisation was no small task in a pastoral region where territorial divisions played - and still play - a major role, and where issues of grazing land, boundaries and frontiers were very sensitive (rumour has it, for instance, that the celebrations at Mount Izmiş, where the districts of Tonya, Şalpazarı and Beşikdüzü converge, were discontinued for several years following a murder between rival groups). Show-casing Trabzon's "(popular) culture" can work only at the cost of such homogenisation.

This touches on Elise Massicard's second point. Transhumance has become something "in common" (a common heritage), meant to concern the worker in Trabzon as much as the grocer settled in Germany, particularly because of these newly-invented urban festivals. This "in common" could be expressed as "we were all transhumants, transhumance is the past of the entity called Trabzon". This common heritage is constructed through two carefully sustained misunderstandings: transhumance is the past of the whole area, and it is the past, not really the present, and - what a grotesque idea! - certainly not the future. This twofold misunderstanding - unity and pastness - is the core operator of transformation into Heritage. One could even call this productive misunderstanding "ideological", a term which carries a heavy charge with it, but which is perhaps the right term for social production through

\footnotetext{
${ }^{20}$ The "upright" horon is a technique of the male body and a process of subjectivation (Elias 2014).
} 
misunderstanding. ${ }^{21}$ Is this not precisely what is at stake when these economically dominated men from the mountains get up on stage and display their masculine dance, which then becomes the heritage and tourist attraction of the whole province? This ideological use of the rural to mask destitution is nothing new. Anne-Marie Thiesse has described the production of national identities in nineteenth-century Europe as follows: "Peasant customs, which were initially considered worthy of interest only as vestiges of some ancestral culture, became symbols of the nation and ethical referents. The peasantry would henceforth serve to prove that despite all the changes one could observe, the nation remained unchanging. The link between the construction of the Nation State, the capitalist economy and industrialisation is evident. But the role played in this configuration by cultural constructs is a singular one: to refute this link". (Thiesse 1999 : 159-160).

Classic examples of the use of a constructed fantasy of transhumance to conceal the effects of industrialisation and the capitalist economy can be found outside the Trabzon province. In all the towns where economic migrants have settled, these celebrations are extremely popular, and have even kept the name of şenlik. The name "Kadırga" in particular has become a selling-point, with emigrants flocking to it. Kadirga festivals are found throughout Turkey - in Istanbul, Orhangazi, and Gölcük - but also in Europe (Amsterdam, Paris, etc.). In 2014, a newspaper even headlined: ${ }^{22}$ "Thousands of people at the Kadirga upland pastures festival" - except that the festival in question, held for the 15th time, was taking place in Ulm, Germany. The content of the newspaper article on the event is particularly instructive, since it presents the recipe for a successful festival - a spotlight on the organisers, known performers for prestige, and a large and undifferentiated public there to celebrate its "traditional" heritage (dance, music, costumes, references to the upland pastures, and so forth):

\footnotetext{
${ }^{21}$ For Adorno, ideology and the culture industry are consubstantial: "Ultimately, the culture industry is no longer even obliged to directly pursue immediate profit, which was its original motivation. Profits have become objectified in the ideology of the culture industry and have even made themselves independent of the need to sell cultural commodities, which must be consumed anyway. The culture industry transforms into public relations, the manufacturing of 'goodwill' per se, without regard for particular producers or saleable objects." Theodor Adorno, "The culture industry reconsidered". 22 «Kadırga yayla şenliğine binlerce kişi katıldı », Haberler.com, published on 24 June 2014, [online] URL : http://www.haberler.com/kadirga-yayla-senligi-ne-binlerce-kisi-katildi-6183079-haberi/
} 
"Held in the town of Markbronn near Ulm (State of Baden-Württemberg), the 15th edition of the 'Kadırga upland pastures festival', organised by the Ulm People of the Black Sea Association and the Trabzonspor Association, was a great success. The five-day-long event attracted visitors from all over Germany, and also from France, Belgium, Holland, Switzerland and Austria [...] It was hosted by Fadime Çebi and Metin Çelik, who welcomed on stage artists such as Selçuk Balcı and his team, Hülya Polat and Gökhan Aydın. The festivities lasted from the early morning to well into the night. The participants were entertained with songs from the Black Sea and horon dances. There were stands with food, clothing and even kemençe for sale, and the area was decked out with posters and flags. Salim Şahin, on stage with his kemençe, described the event as follows 'Here, there are people from every region. Most are from the Black Sea, but with tonight's programme we hope to speak to every region. We will try to entertain everyone without distinction'". ${ }^{23}$

This is an example of the lack of differentiation mentioned previously. Not only is it a vain hope to speak to "every region", but the "narcissism of small differences" characterising local involvement in such celebrations is here breezily ignored. Perhaps the most striking aspect of this distant festival is the association of the vaguest of terms - the "People of the Black Sea" (karadenizli), a category so broad that even in its Turkish sense of the inhabitants of the Eastern Black Sea coast and its emigrants, it still retains a high degree of indetermination and cannot refer to a political community ${ }^{24}$ - and the most precise reference to the Trabzonspor ${ }^{25}$ football club, a commercial enterprise which, even despite itself, exemplifies a highly agressive capitalism. The first term - the "People of the Black Sea" - is clearly an example of "production through misunderstanding" (the production of a category of identity so vague that it is consensually accepted by the largest possible group), ${ }^{26}$ while the second - the Trabzonspor football club - shows who benefits from this misunderstanding. The a-topia suggested above (the region as a purposefully vague category), the lack of differentiation, mask what is a very clear localisation of cultural production and its profits: the

\footnotetext{
${ }^{23}$ Idem.

24 The inhabitants of Kastamonu who settled in Istanbul in the 1950s are still called "Black Sea people" (karadenizli) there.

${ }^{25}$ Trabzonspor, Trabzon-town's football club, is one of the only clubs in the country to challenge the monopoly of the Istanbul clubs (Galatasaray, Beşiktaş et Fenerbahçe). It has a fervent following.

26 "An association is not so much the result of a feeling of common belonging but what produces this. In this sense, one could say that collective mobilisation creates the feeling of belonging, and not the other way round." (Fliche $2007: 207$ ).
} 
town of Trabzon, as the heart of the capitalist economy and more precisely of the culture industry.

\section{A WOLF IN SHEEP'S CLOTHING: THE CITY CELEBRATES TRANSHUMANCE}

Trabzon-town's hold over this process of production could seem unproblematic; after all, it is the province's capital. However, the şenlik arose from an economic system (pastoralism) totally foreign to the industrial town of Trabzon, which has no highland summer quarters, ${ }^{27}$ no transhumance, and a very limited interest in the horon. Here, the homonym "Trabzon-town" and "Trabzon-province" really comes into its own, and is undoubtedly one of the reasons for the town's successful appropriations. We should savour the irony at work, however: the transformation of transhumance into a cultural commodity ultimately benefits the only town in the province which never directly attacked this economic system. Although it always kept a respectable distance from the transhumance economy, it also managed to absorb it by creating a flourishing record industry, several radio stations and four television channels, all of which broadcast the celebrations and music clips showing verdant mountainsides and young girls in traditional dress. The perversity goes so far as to name two of the channels after upland pastures: Zigana TV and ... Kadırga $\mathrm{TV}^{28}$. I should add that there would be no artistic sphere without this cultural industry. For musicians, access to the cultural industry (the possibility of selling one's music) and accession to the status of an artist are obviously linked: the artist is someone who has recorded a CD and whose clips are shown on TV (Elias, 2014). The capitalistic power of Trabzon-town regulates access to the stage - those appearing on stage are those who have the status of an artist - and also reaps the economic benefits, since these performances constitute extra advertising for the artists, whose recordings are sold and whose clips are played again and again by local TV stations. For those who have emigrated, the link between cultural consumption and a sense of belonging to the area is equally evident.

\footnotetext{
${ }^{27}$ We distinguish summer quarters linked to transhumance $(o b a)$ and secondary homes in the mountains to escape the summer heat (yazlik).

${ }^{28}$ Istanbul, the cultural and economic capital of the country, also plays an important role in this cultural industry. Two regional television channels - Karadeniz TV and Mavi Karadeniz TV broadcast from there.
} 
Just as transhumant cultures have been swallowed up by the town, so have the surrounding rural areas. A law passed in 2012 instituted - among twelve others - the "Town Council of Greater Trabzon" (Trabzon Büyüsehir Belediyesi) ${ }^{29}$ and extended its powers to the whole of the province. The law came into force after the local elections of March 2014, and although it is still too early to assess the whole panoply of changes it will bring about, it enacts and highlights the process of making urbanisation the rule. In a short text subtitled "the overwhelming victory of the city in territorial development", Jean-François Pérouse summarises as follows the changes occurring in much of the country: "In other words, the rural no longer exists - the villages of metropolised provinces, which used to have legal personality, have lost this and become urban areas, there is no such thing any more as a small town or a medium-sized town, there are only urban centres, which are the sole agents and hubs of "territorial organisation" in Turkey" (Pérouse, 2012). The ambiguity of Trabzon as the name for both the province and its capital is thus abolished - at least as regards its government - to the exclusive benefit of Trabzon-town, since the whole of the province is henceforth subjected to its rule. Rural zones may have shrunk by 50\% in 40 years (betwen 1965 and 2012), but today, according to the official statistics, they do not exist at all (0\%). The question of the real economic contribution of transhumance to the local economy no longer needs to be asked when this whole economic system is decreed to be undesirable.

One could argue that this change is nothing but an administrative sleight of hand. But it clearly exposes the dialectic between selling transhumance as a cultural commodity and denying its reality as an economic system. The aim of the reform was not to reduce territorial inequalities - which on the contrary increase as rural zones become urban fringes - but to bring the former lands of transhumance into "the sphere of influence and predation of an urban economy", as Jean-François Pérouse puts it (2012). The term "predation" is not too strong. Certain territorial reforms may well have aimed solely at extending the power of the centre, but the most consistent party line over the last ten years has unmistakably been the systematic and brazen involvement of private capital in public works and services. ${ }^{30}$ As such, in Turkey, the promotion of rural areas is left to the discretion of real estate developers.

\footnotetext{
${ }^{29}$ This law (N.6360) introduced 13 new metropolitan municipalities, bringing their total to 30 for all of Turkey.

30 "The AKP has been tempted to sell public goods, and transform them into commodities for tourists or brand vehicles for its agressive marketing of cities" (Pérouse : 2013).
} 


\section{Figure 1 The high pastures of Lişer, Maçka district (Elias)}

Given the above, one would be wrong to think that the State's new involvement in culture went no further than bailing out, and hence institutionalising, some bankrupt festivals. And it would be equally wrong to view festivals as simply spin-offs of national ideology. More important is the way the State has delegated the cultural sphere to private investors, for several decades now. (Pérouse 2004 : 65). Urban-led agressive property development in rural areas throws a more realistic light on the enthusiasm for the summer events calendar and the "festivalisation" of celebrations. What better way to open up new markets for Trabzon's cultural industry, within which transhumance is just one selling-point among others! One does not need much cynicism to suggest that for property developers and the culture industry alike, the hinterland represents above all a regular source of income. And this cultural market by no means stops at the province's borders: marketing, as one of capitalism's tools, will always seek to maximise its public. Transhumance and its associated culture are the smallest common denominators of a vast region - the Pontic Mountains - which in Turkey is called the "Black Sea" (karadeniz) in reference to the coast along which these mountains run. Whoever manages to swallow up transhumance and serve it up again in the form of an economy of festivals, television, radio, recordings, etc., can secure a cultural hegemony over several provinces. In other words, "transhumance" is how a hostile cultural takeover may be introduced through the back door. Trabzon already presided over its province, but Greater Trabzon can hope to build its prestige on a much larger community, well beyond its zone of legitimate power. For example, at the "Rize Days" (Rize Tanttım Günleri), organised in Istanbul to promote Rize's local economy under the patronage of its province, it was artists from Trabzon who paraded on stage. There again, as at Kadırga, some young men defiantly brought their own musician and openly danced at some distance from the event. But Trabzon has its sights set not on these neighbouring provinces, but on the vast pool of emigrants in European exile who are looking for roots, identity and memleket ("native land"). These industrial workers or shopkeepers, who largely come from the economically ruined valleys of transhumance, constitute the public which identifies most readily with Trabzon. And the calendar of celebrations, bearing the official label of the "Provincial Division of Culture and Tourism", seems to be the best way to harness this public to the town's cultural industry. 
Hence if the calendar of pastoral celebrations is far from struggling, if it figures on the website of the "Provincial Division of Culture and Tourism" and is exported like a saleable product, the reason is that it feeds the cultural hegemony of the town of Trabzon, understood both as a regional government and as a concentration of private capital. The (economic) capital of transhumance, reduced to its celebrations, has today been transformed into a schedule of holidays and a time of entertainment (understood as an industry sector under capitalism). Now that it has been confiscated for the benefit of a different system of production, it elicits a quite different collective experience: it produces cultural consumption ${ }^{31}$ as nostalgia, or nostalgia as a cultural product. As such, it provides a structure for a vast public, in the province and beyond. But this show of unity under the banner of transhumance cannot conceal, for those who lived, or still live, from this activity, how brutally they have been stripped of their political power.

\section{BIBLIOGRAPHY}

Adorno, T. 1964. L’industrie culturelle. Communications 3:12-18.

Andrews P.A. and R. Benninghaus, eds. 1989. Ethnic Groups in the Republic of Turkey. Wiesbaden : Dr. Ludwig Reichert Verlag.

Bakırezer, G. 2009. Trabzon Sosyo-ekonomik Çöküşü. In G. Bakırezer, Y. Demirel, eds., Trabzon anlamak. İletişim.

Bourdieu, P. 2012. Sur l'Etat: Cours au Collège de France (1989-1992). Paris : Editions du Seuil.

Bourdieu, P. 1992 [1984]. Homo Academicus. Paris: Editions de Minuit.

Bromberger, C. 1979. Technologie et analyse sémantique des objets : pour une sémiotechnologie. L'Homme 19:105-140.

Çavuş, A. and Altaş N. T. 2010. Trabzon'da Gelişmetkte Olan Bir Turizm Merkezi: Kayabaşi Yaylas1. Doğu Coğrafya Dergisi 23:203-222.

\footnotetext{
${ }^{31}$ One could extend the act of consumption beyond economic transactions and include within it activities such as watching television, listening to a politician's speech, being surrounded by advertising images, etc.
} 
De Planhol, X. 1963. A travers les chaînes pontiques: plantations côtières et vie montagnarde. Bulletin de l'Association des Géographes Français 311:2-12.

Deny, J. 1921. L'adoption du calendrier grégorien en Turquie. Revue du monde musulman 43:46-55.

Dumont, P. 1975. La pacification du sud-est anatolien. Turcica V:108-130

Elias, N. 2014. L'usage communal des sons dans les montagnes pontiques (Turquie). Thèse de doctorat. Université Paris X Nanterre.

Fliche, B. 2007. Odyssées turques. Les migrations d'un village anatolien. Paris : CNRS Editions.

Herzfeld M. 1992. La pratique des stéréotypes. L'Homme 121:67-77

Lortat-Jacob, B. 1994. Musiques en fête. Nanterre: Société d'ethnologie.

Massicard, E. 2005. L'autre Turquie. Le mouvement aléviste et ses territoires. Paris : Presses Universitaires de France.

Massicard, E. 2003. Alevism as a Productive Misunderstanding: the Hacıbektaş Festival. In P. J. White, J. Jongerden, eds., Turkey's Alevi Enigma 125-140. Leiden: Brill.

Pérouse, J.F.. 2004. La Turquie en marche. Les grandes mutations depuis 1980. Paris: Editions de La Martinière.

Pérouse, J.F. 2012. La création de treize nouvelles municipalités métropolitaines par la modification de la loi N.5779 ou le triomphe écrasant de l'urbain dans la gestion de l'ordre territorial. Dipnot [En ligne] URL : http://dipnot.hypotheses.org/37

Pérouse, J.F. 2013. Du régime unique national de production patrimoniale au régime néolibéral, conservateur et partiellement «pluriel » : la Turquie à l'épreuve de la transition patrimoniale. Dipnot [En ligne] URL : http://dipnot.hypotheses.org/127

Thiesse, A.M. 1999. La création des identités nationales. Europe XVIIIe-XXe siècle. Paris : Editions du Seuil.

Yardımcı, S. 2014. Kentsel Değişim ve Festivalizm: Küreselleşen İstanbul'da Bienal. İstanbul: İletişim.

Zaman, M. 2000. Doğu Karadeniz Bölümü Geleneksel Yayla Şenliklerine Tipik Bir Örnek: Kadırga-otçular Şenlikleri. Türk Coğrafya Dergisi 35:277-297.

Zaman, M. 2001. Geleneksel Şenliklerinin Doğu Karadeniz Bölümü Yayla Turizmin Geliştirilmesindeki Rolü. Doğu Coğrafya Dergisi 6:189-214.

Zaman, M. 2010. Doğu Karadeniz Kıyı Dağları'nda Dă̆ ve Yayla Turizmi. Erzurum: Atatürk Üniversitesi Yayınları. 